\title{
False Barriers in the Purchase of Organic Foods. The Case of Extra Virgin Olive Oil in Spain
}

\author{
Francisco José Torres-Ruiz ${ }^{(\mathbb{D}}$, Manuela Vega-Zamora * (i) and Manuel Parras-Rosa \\ Campus Las Lagunillas, University of Jaén, s/n, 23071 Jaén, Spain; ftorres@ujaen.es (F.J.T.-R.); \\ mparras@ujaen.es (M.P.-R.) \\ * Correspondence: mvega@ujaen.es; Tel.: +34-953-213-314
}

Received: 4 January 2018; Accepted: 6 February 2018; Published: 9 February 2018

\begin{abstract}
Although Spain is the world's top organic extra virgin olive oil (OEVOO) producer, domestic consumption is low. Most of the OEVOO produced is destined for external markets. As access to these markets is rife with challenges, developing internal demand has become a matter of utmost importance. Therefore, the general objective of this study is to analyse what is limiting OEVOO consumption levels in Spain. Although a review of the literature reveals some potential explanatory factors, this study analyses the relationship between consumption levels and the limiting factors perceived by consumers. The main novelty of the study is that these limiting factors are divided into two distinct dimensions: difficulties perceived by consumers in the purchase of OEVOO, and the impact of these on their buying behaviour. Based on the results of a survey of 793 people, this distinction throws up a clear paradox: although practically all the factors considered as difficulties are perceived to exist, these do not appear to fully explain the decision not to purchase the product. The suggested explanation for this is simply that the "organic" attribute or label is not highly valued or appreciated by Spanish consumers. Considering the quantitative significance of the group of non-consumers in the population, promoting social and environmental awareness emerges as the best strategy to improve the public's appreciation of the organic label and boost internal demand.
\end{abstract}

Keywords: organic foods; organic extra virgin olive oil; demand; consumption barriers; consumer behaviour

\section{Introduction}

The organic food market has undergone significant growth in the last few decades. Worldwide sales of organic foods grossed 81.6 billion dollars in 2015, five times more than in 1999. Europe generates nearly $40 \%$ of worldwide sales [1].

By way of a brief summary, it is widely assumed that this market growth is the result of a convergence of various drivers, such as the growing interest and investment of consumers, markets and society in general in organic products; the strategic promotion of organic farming at the political level (Common Agricultural Policy, European/state-level/regional plans, etc.); and the conviction of many farmers and agents in the sector that organic farming will allow them to increase their income via a differentiation strategy that gives their products a more competitive edge.

However, growth of the sector in Europe has not been homogenous in all countries. There are certain imbalances between production and consumption, which creates problems of strategic vulnerability in some countries. Spain, for example, boasts the greatest land area dedicated to organic farming in Europe and the fourth greatest in the world, and yet its internal demand is very low (its market share is around $1.5 \%$ and per capita consumption is 32 Euros, figures a long way off those of central and northern European countries such as Switzerland, Luxemburg, Sweden and Denmark) $[2,3]$. 
This imbalance is even more pronounced in the specific case of organic olive oil. In fact, although Spain has the greatest land area dedicated to organic olive growing in the world [4], paradoxically, organic extra virgin olive oil (OEVOO) only represents $0.007 \%$ of per capita spending on foods in Spanish homes [5,6]. This fact is particularly striking, considering the importance of olive oil in Spanish cuisine and culture and the country's position as the world's top producer of olive oils [7]. Household penetration of virgin olive oils is $81.1 \%$ and per capita consumption (according to statistics from the Food Consumption Panel of the Ministry of Agriculture, Fishing, Food and the Environment [6]) is $3.49 \mathrm{~kg}$.

As a result of this imbalance between production and domestic consumption, most of Spain's organic produce in general, and OEVOO in particular, is destined for external markets, which does not seem a particularly sustainable strategy in the long run for various reasons: firstly, the growing preference for locally sourced produce in the destined markets [8,9]; secondly, the concerns of some segments of the market regarding just how "eco-friendly" a product can be when it is transported over hundreds or even thousands of kilometres; and, thirdly, excessive dependence on the export market in a context of increasing competition from third countries.

Given the scenario, increasing the consumption of organic foods in Spain has become a strategic priority for public administrative bodies and agents in the sector [10]. The case of OEVOO is of particularly high priority due to the important role played by organic olive growing in rural settings as a source of income and employment, especially in mountainous areas. Moreover, within the framework of multifunctional agriculture, it is a provider of public goods and healthy, high quality products for the population, it shapes the territory and the culture (playing a key role in territorial and social cohesion and population maintenance in rural areas) and it is of high environmental value (protecting against erosion and climate change and conserving biological diversity).

Finally, two premises should be taken into consideration in this study. Firstly, any increase in consumption ultimately depends on decisions made by the consumer. Secondly, when it comes to organic foods, the barriers highlighted by consumers are of crucial importance in explaining their behaviour. Thus, it seems clear that analysing these barriers would be a good starting point from which to understand the scenario, explain current consumption levels and develop strategies to boost demand. This analysis constitutes the focus of this study, which aims to analyse the relationship between perceived barriers and consumption. The aspects that differentiate this study from the existing literature on this topic are that the consumers are divided into three different categories, and that the barriers are analysed on two different levels: perception of their existence and consideration of their impact on consumer behaviour.

\section{Theoretical Framework: Barriers to the Consumption of Organic Foods}

The level of consumption of organic foods varies according to country [11,12]; however, the differences are not only due to consumer preferences or aspects that drive them to purchase, but also to the barriers that hinder their purchasing behaviour. In short, the existence of motivation to buy organic foods is not enough to develop purchasing behaviour or effective consumption, given that there are also barriers or costs perceived by the consumer that act as a hindrance to this consumption. In fact, despite the highly positive attitudes generally encountered towards organic foods $[13,14]$, it would seem that, in Spain, the factors that hinder their purchase or consumption carry more weight.

Following a comprehensive literature review on consumer behaviour for organic foods, we can conclude that the factors or barriers that hinder consumption are as follows: the high price/price differential between organic products and their conventional equivalents; faults in the commercial distribution of organic foods; consumers' lack of awareness or knowledge of organic foods; consumers' lack of trust or scepticism regarding the authenticity of organic foods and their labelling or certification; the absence of campaigns and actions to inform and educate; the non-homogenous aspect of organic foods (less visually pleasing than conventional equivalents); consumer loyalty for or satisfaction with conventional brands; and a lack of interest in organic foods [15]. Of these limiting factors or barriers, 
the most significant according to the literature are price difference, lack of awareness of organic foods and faulty distribution.

Numerous studies have been conducted in several different countries on the high price differential between organic and conventional foods, focusing on measuring the influence of this limiting factor on organic food consumption. In Spain, to name but a few, we should highlight those of Brugarolas et al. [16], Sánchez et al. [17-19], Gil et al. [20], Soler et al. [21], Parras-Rosa et al. [22] and Vega-Zamora et al. [23]. In all of these studies, the price differential of organic foods is pinpointed as the main or one of the main barriers to consumption and, as such, as an obstacle to the development of the organic market in Spain.

In the same way, the high price of organic foods emerges as one of the main barriers to consumption in many other countries, such as Greece [24-28], Italy [29], Romania [30,31], Croatia [32], Thailand [33], Canada [34], UK [35-38], Brazil [39], Australia [40,41], Ireland [42-44], Sweden [45], Denmark [46,47], USA [48-51], Scotland [52], The Netherlands [53,54], Costa Rica [55], Turkey [56] and Poland [57,58].

In addition to single-country studies, there are those that argue that price is the principal barrier to developing demand in the whole of Europe [11,59] and also in other continents [60,61].

Many authors point out that another limiting factor for consumption of organic foods is consumers' lack of awareness of organic foods and their distinguishing attributes. Soler et al. [21], for example, highlight lack of awareness as one of the main causes of low consumption of organic foods in Spain.

Other countries in which lack of awareness is identified as one of the main reasons for the poor market penetration of organic foods include the USA [48,49], Romania [30], Greece [25,26], the UK [38], Thailand [33], Poland [58] and Brazil [39].

According to Chryssochoidis [62], there is considerable confusion around the term "organic", which perhaps, as Bhaskaran et al. [41] point out, is due in part to the varying use of terminology (such as organic, green or environmentally-friendly) to refer to this type of food product in marketing campaigns. Gleim et al. [61], for their part, examine the factors associated with non-purchasing behaviour for organic foods, suggesting that proper informative labelling may help to overcome the barriers hindering the purchase of this type of food product. Vega-Zamora et al. [13,63] also highlight the widespread lack of awareness and confusion surrounding organic foods in general. Moreover, they argue that, as a result of this, alongside other factors and circumstances, the term or attribute "organic" plays a role as a heuristic cue, i.e., it leads to it being used by consumers not as an end in itself but rather as a means to aspire to other different values.

This lack of awareness regarding organic foods is related to the price differential. Indeed, this problem cannot be disassociated from other limiting factors for consumption of organic foods, since the difference in price between organic and conventional products must, to be accepted, reveal a "product difference", something that many consumers do not perceive. Along these lines of argument, Fraj and Martínez [64] assert that some consumers are not willing to buy and pay more for organic foods because they do not perceive any clear advantages in doing so. In short, the high price is an even greater barrier if the differences between organic and conventional products are not clearly perceived.

Faulty distribution, by which we mean the limited (or lack of) availability of organic food products at regular points of sale, is the other significant obstacle to consumption in most markets, as the consumer experience is that they are difficult to find and that the variety on offer is poor. In Spain, Sánchez et al. [65] and Fraj and Martínez [64] corroborate this problem. They argue that organic product sales in Spain are low mainly due to the insufficient number of establishments selling them, which makes it more difficult for consumers to gain access to them, thus constituting a significant barrier to their consumption.

For some time now, many authors in other countries have made reference to inefficient distribution as a reason for the lack of consumption of organic foods. This is the case in the USA $[48,50,66,67]$, Canada [34], Sweden [45], Ireland [42-44], Norway [68], Scotland [52], the UK [36], Greece [25-28,69], 
Australia [40], Croatia [32], Costa Rica [55], Thailand [33], Turkey [56], Brazil [39], Poland [57,58] and Romania [31].

Wier and Calverley [11] and Schmid et al. [59] maintain that, in Europe, the scarce availability of organic food products is one of the most significant barriers to their purchase.

Given the scenario, Zanoli and Naspetti [29], Lin and Huang [70], Bamberg [71] and Soares et al. [39] insist that better distribution would help to boost the demand for organic foods. Wier and Calverley [11] also specify that, in Europe, a greater availability and variety of organic products in supermarkets would attract consumers who are potentially interested in buying this type of food.

In the same way that lack of awareness of organic foods makes the price differential a highly significant barrier, the commercial distribution model adopted for an organic food product to reach final consumers affects the price and thus also its demand. In the context of low demand, the profit margin policy applied by large-scale distribution outlets raises the price of organic products, therefore disincentivising their consumption [23].

Turning our attention to the literature on consumer behaviour for organic extra virgin olive oil (OEVOO), the first thing we should point out is that there is very little, considering how important the olive oil sector already is for countries of the Mediterranean Basin, and is rapidly becoming in other countries with little or no production, such as the USA, Brazil, Japan, Australia, Germany, Canada, the UK, etc. Spain is the world's top producer of olive oil, with a market share of approximately $50 \%$. In the last 20 years, worldwide consumption of olive oil has doubled from 1,500,000 tons to 3,000,000 tons [7]. This growth has been heavily determined by the behaviour of certain markets that produce little or no olive oil, such as the USA (from 88,000 to 300,000 tons), Brazil (from 13,000 to 70,000 tons), Germany (from 10,000 to 60,000 tons), the UK (from 7000 to 60,000 tons), Japan (from 4,000 to 50,000 tons), Australia (from 13,000 to 40,000 tons) and Canada (from 10,000 to 40,000 tons). On this subject, we should highlight the works of Calatrava [72], Baourakis and Apostolakis [24], Kalogeras et al. [54], Sandalidou et al. [73,74], Parras-Rosa et al. [22], Vega-Zamora et al. [23] and Yangui et al. [75].

Calatrava [72] refers to a matter of interest that is only addressed in the literature on the specific case of olive oil: the influence that consumers' image of conventional olive oil has on the consumption of its organic equivalent. If the conventional product is already highly rated by consumers, it is less likely that consumption of the organic equivalent will increase. The author concludes that there is a lack of interest in OEVOO in Spain because consumers have such a strong appreciation for conventional extra virgin olive oil (CEVOO). Thus, the good image of this product hinders consumption of OEVOO, a barrier associated specifically with the olive oil market and not with other organic food products.

Baourakis and Apostolakis [24], for their part, assert that the high price of OEVOO, together with faulty distribution and consumers' mistrust or scepticism of the authenticity of organic foods and their labelling and certification, are three factors that limit the growth of demand. Sandalidou et al. [74] and Kalogeras et al. [54] reach the same conclusion with regard to the price differential.

Moreover, Sandalidou et al. [73] conclude that consumers' lack of awareness regarding organic foods, alongside the lack of marketing and information campaigns, curb the demand for OEVOO.

Likewise, Parras-Rosa et al. [22] stress that the high price of OEVOO is one of the main explanatory factors for the low demand in Spain. Furthermore, as mentioned previously, Vega-Zamora et al. [23] demonstrate that the OEVOO price differential is influenced by the commercial distribution model, due to the profit margin policy applied by large-scale distribution outlets.

As we have seen above, the barriers to consumption have been addressed extensively in the literature. However, no distinction is made between the perception or awareness of these barriers and the degree to which they affect consumer behaviour, which is the focus given to this study. From this perspective, it is assumed that simple awareness of a barrier or difficulty is a necessary condition, but is not sufficient in itself to hinder consumption, as it is the consumers themselves who decide whether this really affects their buying behaviour. Thus, for example, knowledge of the harmful effects of saturated fats or tobacco on health is not enough to avoid their consumption. 


\section{Materials and Methods}

\subsection{Data Collection}

A survey was conducted of urban olive oil buyers over 25 years old and living in Spain. Data were collected through a structured questionnaire (pretested) that was administered in person on the street, using a personal digital assistant, or PDA. A restricted random sample was used, with quotas by level of education ( $50 \%$ of the sample were university-educated), age (50\% were aged 35 or under) and sex (60\% were women) (Table 1$)$. The literature provides abundant empirical evidence about the influence of these variables on purchasing behaviour and the consumption of organic food [28,33,76-86]. Although the sample was designed to be big enough to adequately represent these demographic strata, the final results showed no significant associations between consumption level and gender, age or education level.

Table 1. Sample.

\begin{tabular}{|c|c|}
\hline Scope & National, Spain \\
\hline Target & Urban buyers of olive oil, aged 25-65 \\
\hline Type of Interview & $\begin{array}{l}\text { Personal interview, in the street, with a PDA, using a structured questionnaire. } \\
\text { Respondents randomly selected in } 10 \text { different locations in each city. }\end{array}$ \\
\hline Sample Size & 793 valid cases \\
\hline Type of Sample & Random. Restricted by age, gender and education level \\
\hline $\begin{array}{l}\text { Final sample } \\
\text { (demographic profile) }\end{array}$ & $\begin{array}{c}\text { Gender: } 59.9 \% \text { female, } 40.1 \% \text { male } \\
\text { Education level: } 14.9 \% \text { primary education, } 35.1 \% \text { secondary education, } 50.0 \% \\
\text { university education } \\
\text { Age: } 50.0 \% \text { (25-35 years old), } 23.8 \% \text { ( } 36-45 \text { years old), } 26.3 \% \text { (>45 years old) }\end{array}$ \\
\hline Sample Error & For global data, $p=q=0.5$ and $\mathrm{k}=1.96$, the sample error is $\pm 3.5 \%$. \\
\hline
\end{tabular}

The interviews were conducted in six different cities: Madrid, Barcelona, Seville, Salamanca, Oviedo and Valencia. The main reason for this choice of cities was their geographical dispersion.

Fieldwork began simultaneously in all cities. A company that designs and conducts market research and opinion campaigns was responsible for carrying out the survey. This company has its own field network and was responsible for programming the PDAs, randomly selecting the respondents (by a 1-3 ratio, using a random number table) from the people who were walking through the 10 sampling locations selected in each city, conducting the interviews and processing the data files, under the supervision of the authors.

\subsection{Measures}

The difficulties or problems that consumers face in the purchase of organic olive oil were measured using two Likert scales comprising six items each. In the first, referring to perceived difficulties, interviewees have to rate their degree of agreement or disagreement with the six items, on a scale of 1 to 5 . These items are statements or declarations regarding the barriers or limiting factors for the purchase of OEVOO, which were drawn from a literature review and a previous qualitative study conducted with four discussion groups in Seville and Madrid (see Vega-Zamora et al. [13,63]). Among all the different statements that arose spontaneously in the conversation, certain points were raised regarding the factors limiting consumption which were generally in keeping with those that emerged in other previous studies. The aim in this part, therefore, is to assess the extent to which consumers believe or consider that these six items or difficulties really exist.

In the second scale, we evaluate whether these perceived difficulties really affect purchasing behaviour, in the opinion of the interviewees. Consumers are asked to rate, on a scale of 1 to 5 , the degree to which each of the six suggested barriers is an important factor for not buying OEVOO. 
In conjunction with this, OEVOO consumption levels were measured on a scale made up of four categories: (1) "I have never tried it"; (2) "I have tried it but I don't use it"; (3) "I use it once or twice a month"; and (4) "I use it more frequently". Three market segments or consumer groups were identified: "non-consumers" belonging to the first and second categories; "occasional consumers" belonging to the third category; and "frequent consumers" belonging to the fourth category.

\subsection{Analysis}

The first stage consisted of analysing whether there are differences on a general level between the three market segments, firstly, in the difficulties perceived, and secondly, in the influence of these on behaviour. This was achieved through a MANOVA, in which the dependent variables were the six items on limiting factors and the independent variable was the type of consumer: "non-consumers", "occasional consumers" and "frequent consumers". Following this, we analysed which specific item or items showed differences, performing an ANOVA for each case. These results were then completed with a post hoc analysis using the Sheffé and Bonferroni methods (equal variances) and Tamhane and Games-Howell methods (unequal variances) to detect which specific groups showed differences.

\section{Results and Discussion}

Of the 793 valid surveys, 665 (83.9\%) were "non-consumers" of OEVOO, 61 (7.7\%) "occasional consumers" and $67(8.44 \%)$ "frequent consumers". Thus, the first relevant result is that only $16.1 \%$ of urban consumers use OEVOO, a figure in keeping with the market situation described in the introduction that leads most of the OEVOO produced in Spain to be destined for export.

\subsection{Perceived Difficulties}

The results of the MANOVA show that the vectors of means of the perceived difficulties in the consumption of OEVOO differ across the three segments. Previously, the existence of significant correlations between beliefs was contrasted and accepted using Bartlett's test of sphericity (approximate chi-square: $459.13 ; p=0.000$ ). Moreover, the $F$ value for the multivariate tests (Pillai's trace, Wilks' lambda, Hotelling's trace and Roy's greatest root) is 9.03 for the first; 9.30 for the second; 9.58 for the third; and 17.84 for the fourth. In all cases, the significance level is below 0.001. Likewise, the ANOVAs performed for each of the six items show significant differences in all but item 4 (Table 2). Thus, confirming the association between these perceptions and consumption frequency. Furthermore, the drop in mean scores as the level of consumption increases shows a coherent association between the two variables. Finally, we should also point out that, on a general level, the difficulties taken into consideration are clearly perceived by consumers, as nearly all the values are above the scale's mean (with the exception of three cases with values just under 3).

Table 2. ANOVAs. Comparison of differences in means between the three consumer groups for each perceived difficulty, means for each group and post hoc analysis.

\begin{tabular}{|c|c|c|c|c|c|}
\hline \multicolumn{3}{|c|}{ Perceived Difficulties: 1. Totally Disagree-5. Totally Agree } & \multicolumn{3}{|c|}{ Means and Post Hoc Analysis } \\
\hline & $F$ Test & $p$ & Non-Consumers & $\begin{array}{l}\text { Occasional } \\
\text { Consumers }\end{array}$ & $\begin{array}{l}\text { Frequent } \\
\text { Consumers }\end{array}$ \\
\hline 1. Takes longer to locate inside the store & 6.700 & 0.001 & $4.02^{b}$ & 3.72 & $3.56^{\mathrm{b}}$ \\
\hline $\begin{array}{l}\text { 2. Difficult to tell it apart from other high quality } \\
\text { olive oils }\end{array}$ & 11.979 & 0.000 & $3.49^{\mathrm{a}, \mathrm{b}}$ & $2.95^{\mathrm{a}}$ & $2.89^{b}$ \\
\hline 3. The non-organic product is good enough for me & 37.233 & 0.000 & $4.04^{\mathrm{a}, \mathrm{b}}$ & $3.41^{\mathrm{a}}$ & $2.95^{\mathrm{b}}$ \\
\hline 4. More difficult to find in any type of store & 1.039 & 0.354 & 3.82 & 3.81 & 3.60 \\
\hline $\begin{array}{l}\text { 5. More difficult to find the organic product in the } \\
\text { stores where I usually shop }\end{array}$ & 21.968 & 0.000 & $4.06^{\mathrm{b}}$ & $3.71^{\mathrm{c}}$ & $3.16^{b, c}$ \\
\hline $\begin{array}{l}\text { 6. The price difference between organic and } \\
\text { non-organic olive oil is high }\end{array}$ & 9.400 & 0.000 & $4.15^{b}$ & $4.14^{\mathrm{c}}$ & $3.60^{b, c}$ \\
\hline
\end{tabular}


As anticipated, the post hoc analysis highlights that, in terms of the intensity with which the difficulties are perceived, the greatest discrepancies are found between the "non-consumers" and the "frequent consumers", with the scores polarized between the two groups.

On another note, the differences in perceptions between occasional and frequent consumers are found in the items on price difference and availability in stores where they usually shop, factors considered to be related to marketing and distribution problems.

However, the main distinctive features of "non-consumers", especially with respect to occasional consumers, are related to the intrinsic value of the product. From this perspective, it is clear that they find it more difficult to distinguish from the conventional kind, which they feel is already good enough for them. Of course, in attempts to drive market change or boost demand, these problems are much more difficult to overcome than those of a more external nature related to marketing issues (price or distribution). In short, although the main way to increase demand, given the considerably larger size of the group, is to persuade these non-consumers to buy the product, it appears to be a highly difficult task because they simply do not value it.

\subsection{Impact of Perceived Difficulties on Purchasing Behaviour}

As we explained above, the perception of difficulties is only the first step and the results must be completed with the degree to which this affects consumption. The MANOVA results show that the impact of the difficulties on consumption varies according to the consumer group. Previously, the existence of significant correlations between beliefs was contrasted and accepted using Bartlett's test of sphericity (approximate chi-square: 1447.32; $p=0.000$ ). Moreover, the $F$ value for the multivariate tests (Pillai's trace, Wilks' lambda, Hotelling's trace and Roy's greatest root) is 6.69 for the first; 6.76 for the second; 6.84 for the third; and 11.48 for the fourth. In all cases, the significance level is below 0.001 . Likewise, the ANOVAs demonstrate that for all the items, the scores for the three groups are different, as can be seen in Table 3 .

Table 3. ANOVAs. Comparison of differences in means between the three consumer groups for the effect of perceived difficulties on purchasing behaviour, means for each group and post hoc analysis.

\begin{tabular}{|c|c|c|c|c|c|}
\hline \multicolumn{3}{|c|}{$\begin{array}{c}\text { Effect of Perceived Difficulties: (1) “No, It Doesn't Affect it at All"-(5) “Yes, } \\
\text { It's an Important Reason for not Buying OEVOO" }\end{array}$} & \multicolumn{3}{|c|}{ Means and Post Hoc Analysis } \\
\hline & $F$ test & $p$ & Non-Consumers & $\begin{array}{l}\text { Occasional } \\
\text { Consumers }\end{array}$ & $\begin{array}{c}\text { Frequent } \\
\text { Consumers }\end{array}$ \\
\hline 1. Takes longer to locate inside the store & 4.821 & 0.008 & $3.30^{\mathrm{b}}$ & 3.05 & $2.78^{\mathrm{b}}$ \\
\hline 2. Difficult to tell it apart from other high quality olive oils & 13.551 & 0.000 & $3.15^{\mathrm{a}, \mathrm{b}}$ & $2.54^{\mathrm{a}}$ & $2.46^{\mathrm{b}}$ \\
\hline 3. The non-organic product is good enough for me & 16.386 & 0.000 & $3.56^{\mathrm{a}, \mathrm{b}}$ & $2.98^{\mathrm{a}}$ & $2.77^{\mathrm{b}}$ \\
\hline 4. More difficult to find in any type of store & 8.733 & 0.000 & $3.32^{b}$ & 3.10 & $2.63^{\mathrm{b}}$ \\
\hline $\begin{array}{l}\text { 5. More difficult to find the organic product in the stores } \\
\text { where I usually shop }\end{array}$ & 13.774 & 0.000 & $3.48^{\mathrm{b}}$ & $3.20^{c}$ & $2.60^{b, c}$ \\
\hline $\begin{array}{l}\text { 6. The price difference between organic and non-organic olive } \\
\text { oil is high }\end{array}$ & 24.845 & 0.000 & $3.85^{\mathrm{b}}$ & $3.62^{c}$ & $2.77^{b, c}$ \\
\hline
\end{tabular}

Again, we can clearly observe the polarization of scores at opposite ends of the consumer group scale, and the drop in scores in line with the increase in consumption frequency. This allows us to confirm the association between the two variables, i.e., consumption level and the assumption that the perceived difficulties limit it. Furthermore, we should point out that the scores are lower than those obtained in the other scale, in keeping with our starting hypothesis. In other words, given that the perception of difficulties is greater than the effect these have on behaviour, we can assume that dividing the analysis of barriers into these two dimensions is a pertinent exercise, and that the mere perception of these difficulties is not enough in itself to explain consumption levels.

In this case, although "frequent consumers" perceive that the price difference and difficulties finding OEVOO in their normal stores are problems that exist in the market, these do not affect their 
decision to purchase, whereas the same cannot be said of "occasional consumers", who are affected by them.

The generally low appreciation of OEVOO among "non-consumers" is the main difference in behaviour with respect to "occasional consumers". The "organic" attribute does not represent any added value for the "non-consumers" so it does not generate any interest in the product. This lack of interest, in all likelihood, perpetuates the scant level of knowledge and awareness of organic products, making them difficult to identify and limiting their consumption.

Of all the barriers or difficulties considered here, there are three for which the scores are higher in all the groups and, moreover, there is a greater difference or polarization between groups, thus these are probably the factors or barriers that are most related to the different levels of consumption. These results are in keeping with those of Calatrava [72], Baourakis and Apostolakis [24], Sandalidou et al. [74], Kalogeras et al. [54] and Parras-Rosa et al. [22].

We should point out that two of these barriers-"more difficult to find the organic product in the stores where I usually shop" and "the price difference between organic and non-organic olive oil is high" - are limiting factors related to general convenience and these could be changed to boost demand. The third, however, poses a real problem: OEVOO is not more highly appreciated than CEVOO, and this situation is more difficult to change as it is tied to values and environmental awareness.

\subsection{Joint Consideration of Perceived Difficulties and Barriers}

In this case, when we discuss barriers, we are referring to the perceived difficulties that influence purchasing behaviour by limiting or hindering it, i.e., those difficulties that are perceived and that really drive the decision not to purchase OEVOO.

To obtain an overall explanation of the situation of OEVOO demand, it is useful to draw a comparison between the two variables. At the global level, it is clear that the perception of difficulties is general to all groups and that the level of perception is high, although it varies according to the consumer group. In the same way, we can see that these difficulties affect the behaviour of the three consumer groups in different ways. It stands to reason that, although they are perceived, they do not significantly affect the groups that consume OEVOO, but they do affect the "non-consumers". With regard to this group, which is the largest and most significant in terms of increasing demand, an important point should be made: the perceived difficulties are more pronounced than their impact on consumption, which is a surprising result given that they do not consume the product. In other words, it would be logical to assume that these difficulties (or at least some of them) would be considered the factors or barriers that consumers use as an argument for not buying OEVOO, and that this group's scores would be near the top of the scale. This is not the case, however, as none of the mean values even reach 4 , and in all cases the values are lower than those for perceived difficulties (Table 4).

Table 4. "Non-consumers" group. T-test (paired observations), between the scale of perceived difficulties ("Totally disagree" (1)-“Totally agree" (5)) and the scale of effect on consumption ((1) “No, it doesn't affect it at all"-(5) “Yes, it's an important reason for not buying it").

\begin{tabular}{|c|c|c|c|c|}
\hline Items & $\begin{array}{l}\text { Difference } \\
\text { in Means }\end{array}$ & Std. Dev. & $T$ & Sig. \\
\hline 1. Takes longer to locate inside the store & 0.746 & 1.485 & 11.139 & 0.000 \\
\hline 2. Difficult to tell it apart from other high quality olive oils & 0.390 & 1.241 & 6.876 & 0.000 \\
\hline 3. The non-organic product is good enough for me & 0.595 & 1.403 & 9.830 & 0.000 \\
\hline 4. More difficult to find in any type of store & 0.527 & 1.365 & 8.744 & 0.000 \\
\hline 5. More difficult to find the organic product in the stores where I usually shop & 0.644 & 1.355 & 10.730 & 0.000 \\
\hline 6. The price difference between organic and non-organic olive oil is high & 0.308 & 1.033 & 6.490 & 0.000 \\
\hline
\end{tabular}

How can this paradox be explained? How is it possible that a group of consumers does not buy the product, perceives difficulties or limiting factors, and yet does not give any clear indication that these difficulties directly determine the decision not to purchase? There are two possible reasons for 
this. The first is that the factors used in the study are not determinants of consumption, an idea which must be rejected out of hand, as it would cast doubt on a large part of the theoretical and empirical literature on the subject, as well as on the results obtained in this study, in which we can clearly observe the association between consumption level and the factors considered to act as barriers.

The second reason may shed more light on this apparent paradox. We should consider that perhaps it is less a question of barriers than of mere interest or desire. In other words, this group of consumers simply does not value the "organic" attribute highly enough and therefore has no desire for or interest in OEVOO. This is not a case of a product which is not purchased due to a series of perceived difficulties. The explanation is much more basic and straightforward than that: there is a lack of interest and desire; OEVOO is not more highly valued than CEVOO, its differential attribute is of no interest to this consumer group and, moreover, it is more expensive. In short, difficulties are perceived, but they are not real barriers to purchasing OEVOO. The real barrier is the product itself, as its organic attribute is not desired or sufficiently highly valued by consumers.

A final point to be made, given the considerable attention paid to demographic characteristics in the literature, is that our results did not reveal any significant associations with age, gender or education level.

\section{Conclusions}

This study analyses the relationship between perceived barriers and consumption of an organic product, OEVOO. Although the influence of determined barriers on the consumption of organic foods has been widely discussed in the scientific literature, this study presents two distinguishing elements. Firstly, three groups of consumers were taken into consideration in the analysis, and, secondly, a different focus was adopted which consisted of dividing the barriers into two distinct dimensions: perceived difficulties and the impact of these on behaviour (barriers).

This distinction rests on the hypothesis that the perception of difficulties does not in itself explain the level of consumption, given that different groups of consumers can perceive the same difficulties and yet display different purchasing behaviour. In other words, the same perceptions can affect different consumers in different ways. This new focus allows us to better understand the reasons why OEVOO consumption is inhibited and to steer strategies to boost its demand.

In this approach, the main features that characterize the influence of limiting factors on consumption are as follows: (1) the difficulties considered are clearly perceived as such by the three groups of consumers; (2) these difficulties affect purchasing behaviour, i.e., they limit OEVOO consumption; and (3) the two previous results vary according to the consumer group, i.e., they are related to or serve to explain the level of consumption. However, we detected that for "non-consumers", the perceived difficulties do not appear to represent real reasons for not buying the product, given the difference in scores between their perception of these difficulties and their opinion on the effect of these on purchasing behaviour.

Of the possible explanations for this paradox, perhaps the one most in keeping with previous literature is the consideration that the real problem limiting demand is not a barrier or a series of barriers, but rather a lack of appreciation and desire for the "organic" attribute on the part of this group of consumers. The real limiting factor is the product, OEVOO itself, whose organic characteristics do not represent added value to these consumers.

In terms of the practical implications of this study, these results may be of use in the design of different strategies to boost demand according to consumer group. For those that already consume the product, efforts should be made to reduce the price differential between OEVOO and CEVOO and achieve greater efficiency in distribution, which are sales and marketing-related strategies. For the group of "non-consumers", by far the most numerous and important for increasing demand, strategies should revolve around achieving greater social and environmental awareness to encourage a greater appreciation of the "organic" attribute, and thus of organic food products in general and OEVOO in 
particular. To achieve this, policies promoting the consumption of organic foods are essential, driven and led by public organizations to ensure their effectiveness.

Finally, in terms of the limitations of this study, one question emerges that may open further lines of research, which is whether this lack of appreciation of the "organic" attribute is specific to certain organic products such as OEVOO and what reasons there may be for this, given that, according to the literature, organic foods are generally highly valued by consumers.

Acknowledgments: This work was funded by the Regional Government of Andalusia (Spain) through the "Estrategias de marketing del aceite de oliva ecológico en el mercado español" (Marketing strategies for organic olive oil on the Spanish market) research project and the "Estrategias de mejora de la comercialización de los aceites de olive" (Strategies to improve olive oil marketing) Excellence project (AGR-6132). The authors wish to thank Katherine Bartlett for English-language editing assistance.

Author Contributions: Francisco José Torres-Ruiz, Manuela Vega-Zamora and Manuel Parras-Rosa conceived, designed and performed the research. Francisco José Torres-Ruiz, Manuela Vega-Zamora and Manuel Parras-Rosa analysed the data and wrote the paper.

Conflicts of Interest: The authors declare no conflict of interest.

\section{References}

1. Sahota, A. The global market for organic food \& drink. In The World of Organic Agriculture. Statistics and Emerging Trends 2017; Willer, H., Lernoud, J., Eds.; Research Institute of Organic Agriculture (FiBL) and International Federation of Organic Agriculture Movements (IFOAM): Frick, Switzerland; Bonn, Germany, 2017; pp. 138-142, ISBN 978-3-03736-040-8.

2. Lernoud, J.; Willer, H. Current statistics on organic agriculture worldwide: Area, operators, and market. In The World of Organic Agriculture. Statistics and Emerging Trends 2017; Willer, H., Lernoud, J., Eds.; Research Institute of Organic Agriculture (FiBL) and International Federation of Organic Agriculture Movements (IFOAM): Frick, Switzerland; Bonn, Germany, 2017; pp. 36-75, ISBN 978-3-03736-040-8.

3. Willer, H.; Schaack, D.; Lernoud, J. Organic farming and market development in Europe and the European Union. In The World of Organic Agriculture. Statistics and Emerging Trends 2017; Willer, H., Lernoud, J., Eds.; Research Institute of Organic Agriculture (FiBL) and International Federation of Organic Agriculture Movements (IFOAM): Frick, Switzerland; Bonn, Germany, 2017; pp. 207-243, ISBN 978-3-03736-040-8.

4. Lernoud, J.; Willer, H. Land use and commodities in organic agriculture. In The World of Organic Agriculture. Statistics and Emerging Trends 2017; Willer, H., Lernoud, J., Eds.; Research Institute of Organic Agriculture (FiBL) and International Federation of Organic Agriculture Movements (IFOAM): Frick, Switzerland; Bonn, Germany, 2017; pp. 78-135, ISBN 978-3-03736-040-8.

5. Ministerio de Agricultura, Pesca, Alimentación y Medio Ambiente. Informe del Consumo de Alimentación en España 2014. Available online: http://www.magrama.gob.es/es/alimentacion/temas/consumo-ycomercializacion-y-distribucion-alimentaria/informeconsumoalimentacion2014_tcm7-382148.pdf (accessed on 10 March 2016).

6. Ministerio de Agricultura, Pesca, Alimentación y Medio Ambiente. Base de datos de Consumo en Hogares. Año 2013. Available online: http:/ / www.magrama.gob.es/es/alimentacion/temas / consumo-ycomercializacion-y-distribucion-alimentaria/panel-de-consumo-alimentario/base-de-datos-de-consumoen-hogares/consulta.asp (accessed on 12 March 2017).

7. International Olive Council. Available online: http://www.internationaloliveoil.org/estaticos/view/131world-olive-oil-figures (accessed on 15 December 2017).

8. Brugarolas, M.; Rivera, L.M. Comportamiento del consumidor valenciano ante los productos ecológicos e integrados. Revista Española de Estudios Agrosociales y Pesqueros 2002, 192, 105-212.

9. Cosmina, M.; Gallenti, G.; Maragon, F.; Troiano, S. Attitudes towards honey among Italian consumers: A choice experiment approach. Appetite 2016, 99, 52-58. [CrossRef] [PubMed]

10. Ministerio de Agricultura, Pesca, Alimentación y Medio Ambiente. Estrategia Para el Apoyo a la Producción Ecológica. Available online: http://www.magrama.gob.es/es/alimentacion/temas/laagricultura-ecologica/Estrategia_Apoyo_Producci\%C3\%B3n_Ecol\%C3\%B3gica_tcm7-319074.pdf (accessed on 10 March 2016).

11. Wier, M.; Calverley, C. Market potential for organic food in Europe. Br. Food J. 2002, 104, 45-62. [CrossRef] 
12. Thøgersen, J. Country differences in sustainable consumption: The case of organic food. J. Macromark. 2010, 30, 171-185. [CrossRef]

13. Vega-Zamora, M.; Torres-Ruiz, F.J.; Murgado-Armenteros, E.M.; Parras-Rosa, M. Organic as a heuristic cue: What Spanish consumers mean by organic foods. Psychol. Mark. 2014, 31, 349-359. [CrossRef]

14. Qendro, A.E. Albanian and UK consumers' perceptions of farmers' markets and supermarkets as outlets for organic food: An exploratory study. Sustainability 2015, 7, 6626-6651. [CrossRef]

15. Vega-Zamora, M.; Parras-Rosa, M.; Torres-Ruiz, F.J.; Murgado-Armenteros, E.M. Los factores impulsores e inhibidores del consumo de alimentos ecológicos en España. El caso del aceite de oliva. Interciencia 2011, 36, 178-184.

16. Brugarolas, M.; Rivera, L.M.; Sánchez, M. Potencial de mercado para nuevos productos alimentarios: La producción ecológica. Investig. Eur. Dir. Econ. Empres. 1997, 3, 61-76.

17. Sánchez, M.; Gil, J.; Gracia, A. Frenos al crecimiento del mercado ecológico: ¿el precio o la actitud hacia el medio ambiente? Rev. Esp. Investig. Mark. 1998, 2, 103-116.

18. Sánchez, M.; Grande, I.; Gil, J.; Gracia, A. Evaluación del potencial de mercado de los productos de agricultura ecológica. Rev. Esp. Investig. Mark. 1998, 2, 135-150.

19. Sánchez, M.; Grande, I.; Gil, J.; Gracia, A. Diferencias entre los segmentos del mercado en la disposición a pagar por un alimento ecológico: Valoración contingente y análisis conjunto. Revista Española de Estudios Agrosociales y Pesqueros 2001, 190, 141-163.

20. Gil, J.M.; Gracia, A.; Sánchez, M. Market segmentation and willingness to pay for organic products in Spain. Int. Food Agribus. Manag. Rev. 2000, 3, 207-226. [CrossRef]

21. Soler, F.; Gil, J.M.; Sánchez, M. Consumers' acceptability of organic food in Spain. Results from an experimental auction market. Br. Food J. 2002, 104, 670-687. [CrossRef]

22. Parras-Rosa, M.; Vega-Zamora, M.; Gutiérrez-Salcedo, M. El sobreprecio del aceite de oliva ecológico frente al del convencional a nivel minorista, como factor explicativo de su escasa cuota de ventas en España. Revista Española de Estudios Agrosociales y Pesqueros 2011, 229, 145-160.

23. Vega-Zamora, M.; Parras-Rosa, M.; Torres-Ruiz, F.J. Influence of the commercial distribution model on the surcharge for organic foods in Spain. J. Food Agric. Environ. 2013, 11, 285-290. [CrossRef]

24. Baourakis, G.; Apostolakis, I. A statistical assessment of consumers' criteria regarding organic agricultural products: The case of organic olive oil. Found. Comput. Decis. Sci. 1999, 24, 21-31.

25. Fotopoulos, C.; Krystallis, A. Organic product avoidance. Reasons for rejection and potential buyers' identification in a countrywide survey. Br. Food J. 2002, 104, 233-260. [CrossRef]

26. Fotopoulos, C.; Krystallis, A. Purchasing motives and profile of the Greek organic consumer: A countrywide survey. Br. Food J. 104, 730-765. [CrossRef]

27. Botonaki, A.; Polymeros, K.; Tsakiridou, E.; Matas, K. The role of quality certification on consumers' food choices. Br. Food J. 2006, 108, 77-90. [CrossRef]

28. Tsakiridou, E.; Boutsouki, C.; Zotos, Y.; Mattas, K. Attitudes and behaviour towards organic products: An exploratory study. Int. J. Retail Distrib. Manag. 2008, 36, 158-175. [CrossRef]

29. Zanoli, R.; Naspetti, S. Consumer motivations in the purchase of organic food. A means-end approach. Br. Food J. 2002, 104, 643-653. [CrossRef]

30. Lubieniechi, S.A. Romanian consumers' behaviour regarding organic food. Br. Food J. 2002, 104, 337-344. [CrossRef]

31. Petrescu, D.C.; Petrescu-Mag, R.M.; Burny, P.; Azadi, H. A new wave in Romania: Organic food. Consumers' motivations, perceptions, and habits. Agroecol. Sustain. Food Syst. 2017, 41, 46-75. [CrossRef]

32. Radman, M. Consumer consumption and perception of organic products in Croatia. Br. Food J. 2005, 107, 263-273. [CrossRef]

33. Roitner-Schobesberger, B.; Darnhofer, I.; Somsook, S.; Vogl, C.R. Consumer perceptions of organic foods in Bangkok, Thailand. Food Policy 2008, 33, 112-121. [CrossRef]

34. Hamzaoui, L.; Zahaf, M. Decision making process of community organic food consumers: An exploratory study. J. Consum. Mark. 2008, 25, 95-104. [CrossRef]

35. Tregear, A.; Dent, J.B.; McGregor, M.J. The demand for organically-grown produce. Br. Food J. 1994, 96, 21-25. [CrossRef]

36. Hill, H.; Lynchehaun, F. Organic milk: Attitudes and consumption patterns. Br. Food J. 2002, 104, 526-542. [CrossRef] 
37. McEachern, M.G.; Willock, J. Producers and consumers of organic meat: A focus on attitudes and motivations. Br. Food J. 2004, 106, 534-552. [CrossRef]

38. Padel, S.; Foster, C. Exploring the gap between attitudes and behaviour. Understanding why consumers buy or do not buy organic food. Br. Food J. 2005, 107, 606-625. [CrossRef]

39. Soares, L.L.S.; Deliza, R.; Oliveira, S.P. The Brazilian consumer's understanding and perceptions of organic vegetables: A focus group approach. Cienc. Tecnol. Aliment. 2008, 28, 241-246. [CrossRef]

40. Lea, E.; Worsley, T. Australians' organic food beliefs, demographics and values. Br. Food J. 2005, 107, 855-869. [CrossRef]

41. Bhaskaran, S.; Polonsky, M.; Cary, J.; Fernandez, S. Environmentally sustainable food production and marketing: Opportunity or hype? Br. Food J. 2006, 108, 677-690. [CrossRef]

42. Davies, A.; Titterington, A.J.; Cochrane, C. Who buys organic food? A profile of the purchasers of organic food in Northern Ireland. Br. Food J. 1995, 97, 17-23. [CrossRef]

43. Roddy, G.; Cowan, C.A.; Hutchinson, G. Consumer attitudes and behaviour to organic foods in Ireland. J. Int. Consum. Mark. 1996, 9, 41-63. [CrossRef]

44. O’Donovan, P.; McCarthy, M. Irish consumer preference for organic meat. Br. Food J. 2002, 104, $353-370$. [CrossRef]

45. Magnusson, M.; Arvola, A.; Koivisto, U.; Aberg, L.; Sjoden, P. Attitudes towards organic foods among Swedish consumers. Br. Food J. 2001, 103, 209-227. [CrossRef]

46. Grunert, S.C.; Kristensen, K. Den Danske Forbruger og Okologiske Fodevarer; Working Papers in Marketing, No 1; Department of Marketing, Odense University: Odense, Denmark, 1995.

47. Marian, L.; Chrysochou, P.; Krystallis, A.; Thogersen, J. The role of price as a product attribute in organic food context: An exploration based on actual purchase data. Food Qual. Preference 2014, 37, 52-60. [CrossRef]

48. Demeritt, L. All Things Organic 2002: A Look at the Organic Consumer; The Hartman Group: Bellevue, WA, USA, 2002.

49. Zepeda, L.; Chang, H.S.; Leviten-Reid, C. Organic food demand: A focus group study involving Caucasian and African-American shoppers. Agric. Hum. Values 2006, 23, 385-394. [CrossRef]

50. Van Loo, E.; Caputo, V.; Nayga, R.M.; Meullenet, J.F.; Crandall, P.G.; Ricke, S.C. Effect of organic poultry purchase frequency on consumer attitudes toward organic poultry meat. J. Food Sci. 2010, 75, S384-S397. [CrossRef] [PubMed]

51. Wang, Q.; Sun, J.; Parsons, R. Consumer preferences and willingness to pay for locally grown organic apples: Evidence from a conjoint study. Hortscience 2010, 45, 376-381.

52. McEachern, M.G.; McClean, P. Organic purchasing motivations and attitudes: Are they ethical? Int. J. Consum. Stud. 2002, 26, 85-92. [CrossRef]

53. Verhoef, P. Explaining purchases of organic meat by Dutch consumers. Eur. Rev. Agric. Econ. 2005, 32, 245-267. [CrossRef]

54. Kalogeras, N.; Valchovska, S.; Baourakıs, G.; Kalaitz1s, P. Dutch consumers' willingness to pay for organic olive oil. J. Int. Food Agribus. Mark. 2009, 21, 286-311. [CrossRef]

55. Aguirre, G.J.A. The farmer's market organic consumer of Costa Rica. Br. Food J. 2007, 109, 145-154. [CrossRef]

56. Aygen, F.G. Attitudes and behavior of Turkish consumers with respect to organic foods. Int. J. Bus. Soc. Sci. 2012, 3, 262-273.

57. Bryla, P. Marketing of ecological food products—Results of a research study among Polish processors. Rocznik Ochrona Srodowiska 2013, 15, 2899-2910. [CrossRef]

58. Bryla, P. Organic food consumption in Poland: Motives and barriers. Appetite 2016, 105, 737-746. [CrossRef] [PubMed]

59. Schmid, O.; De Fontguyon, G.; Sans, P. Desarrollo del mercado de productos de la agricultura ecológica en Europa: Un análisis de sus condiciones y del papel de las iniciativas comerciales. Revista Española de Estudios Agrosociales y Pesqueros 2007, 214, 15-44.

60. Thompson, G. Consumer demand for organic foods. HortScience 1999, 34, 558.

61. Gleim, M.R.; Smith, J.S.; Andrews, D.; Cronin, J.J. Against the green: A multi-method examination of the barriers to green consumption. J. Retail. 2013, 89, 44-61. [CrossRef]

62. Chryssohoidis, G.M. Repercussions of consumer confusion for late introduced differentiated products. Eur. J. Mark. 2000, 34, 705-722. [CrossRef] 
63. Vega-Zamora, M.; Parras-Rosa, M.; Murgado-Armenteros, E.M.; Torres-Ruiz, F.J. A powerful word: The influence of the term "organic" on perceptions and beliefs concerning food. Int. Food Agribus. Manag. Rev. 2013, 16, 51-76.

64. Fraj, E.; Martínez, E. Influencia de las características demográficas y socioeconómicas de los consumidores en la compra de productos ecológicos. Estudios Sobre Consumo 2003, 65, 9-20.

65. Sánchez, M.; Etxaniz, M.; Tekelioglu, I. Análisis de las preferencias en el consumo de productos de agricultura ecológica. Estudios Sobre Consumo 1997, 41, 49-63.

66. Jolly, D. Differences between buyers and nonbuyers of organic produce and willingness to pay organic price premiums. J. Agribus. 1991, 9, 97-111.

67. Byrne, P.J.; Toensmeyer, U.C.; German, C.L.; Muller, H.L. Evaluation of consumer attitudes towards organic produce in Delaware and the Delmarva region. J. Food Distrib. Res. 1992, 23, 29-44.

68. Wandel, M.; Bugge, A. Environmental concern in consumer evaluation of food quality. Food Qual. Preference 1997, 8, 19-26. [CrossRef]

69. Zotos, Y.; Ziamou, P.; Tsakiridou, E. Marketing Organically Produced Food Products in Greece; Greener Management International; Greenleaf Publishing: Yorkshire, UK, 1999; pp. 91-104.

70. Lin, P.C.; Huang, Y.H. The influence factors on choice behavior regarding green products based on the theory of consumption values. J. Clean. Prod. 2012, 22, 11-18. [CrossRef]

71. Bamberg, S. Implementation intention versus monetary incentive comparing the effects of interventions to promote the purchase of organically produced food. J. Econ. Psychol. 2002, 23, 573-587. [CrossRef]

72. Calatrava, J. Actitudes del consumidor español respecto a los productos ecológicos: Análisis de relación entre la recepción de la calidad y la Disposición a Pagar (DAP) por los aceites de oliva. In Proceedings of the II Jornadas Mediterráneas de Olivar Ecológico y Ecología del Aceite de Oliva, Puente de Génave, Spain, 21-23 May 1998.

73. Sandalidou, E.; Baourakis, G.; Siskos, Y. Customers' perspectives on the quality of organic olive oil in Greece: A satisfaction evaluation approach. Br. Food J. 2002, 104, 391-406. [CrossRef]

74. Sandalidou, E.; Baourakis, G.; Grigoroudis, E.; Siskos, Y. Organic and conventional olive oil consumers: A comparative analysis using a customer satisfaction evaluation approach. Cahiers Options Méditerranéennes 2003, 61, 265-276.

75. Yangui, A.; Costa-Font, M.; Gil, J.M. The effect of personality traits on consumers' preferences for extra virgin olive oil. Food Qual. Preference 2016, 51, 27-38. [CrossRef]

76. Storstad, O.; Bjorkhaug, H. Foundations of production and consumption of organic food in Norway: Common attitudes among farmers and consumers? Agric. Hum. Values 2003, 20, 151-163. [CrossRef]

77. Lockie, S.; Lyons, K.; Lawrence, G.; Grice, J. Choosing organics: A path analysis of factors underlying the selection of organic food among Australian consumers. Appetite 2004, 43, 135-146. [CrossRef] [PubMed]

78. Onyango, B.M.; Hallman, W.K.; Bellows, A.C. Purchasing organic food in US food systems. A study of attitudes and practice. Br. Food J. 2007, 109, 399-411. [CrossRef]

79. Justin, P.; Jyoti, R. Consumer behavior and purchase intention for organic food. J. Consum. Mark. 2012, 29, 412-422.

80. Dimitri, C.; Dettmann, R.L. Organic food consumers: What do we really know about them? Br. Food J. 2012, 114, 1157-1183. [CrossRef]

81. Tung, S.J.; Shih, C.C.; Wei, S.; Chen, Y.H. Attitudinal inconsistency toward organic food in relation to purchasing intention and behavior: An illustration of Taiwan consumers. Br. Food J. 2012, 114, 997-1015. [CrossRef]

82. Rezai, G.; Teng, P.K.; Mohamed, Z.; Shamsudin, M.N. Consumers' awareness and consumption intention towards green foods. Afr. J. Bus. Manag. 2012, 6, 4496-4503. [CrossRef]

83. Petrescu, D.C.; Petrescu-Mag, R.M. Organic food perception: Fad, or healthy and environmentally friendly? A case on Romanian consumers. Sustainability 2015, 7, 12017-12031. [CrossRef]

84. Laureti, T.; Benedetti, I. Exploring pro-environmental food purchasing behaviour: An empirical analysis of Italian consumers. J. Clean. Prod. 2018, 172, 3367-3378. [CrossRef] 
85. Davidson, D.J.; Freudenburg, W.R. Gender and environmental risk concerns: A review and analysis of available research. Environ. Behav. 1996, 28, 302-339. [CrossRef]

86. Diamantopoulos, A.; Schlegelmilch, B.B.; Sinkovics, R.R.; Bohlen, G.M. Can socio-demographics still play a role in profiling green consumers? A review of the evidence and an empirical investigation. J. Bus. Res. 2003, 56, 465-480. [CrossRef] 